\title{
Good sensory recovery of the hand in brachial plexus surgery using the intercostobrachial nerve as the donor
}

\author{
Boa recuperação da sensibilidade da mão usando o nervo intercostobraquial como doador \\ em cirurgia do plexo braquial
}

Luciano Foroni1, Mário Gilberto Siqueira ${ }^{1}$, Roberto Sérgio Martins ${ }^{1}$, Carlos Otto Heise ${ }^{2,3}$, Hugo Sterman

Neto ${ }^{4}$, Adriana Yoriko Imamura ${ }^{5}$

\begin{abstract}
Objective: Restoration of the sensitivity to sensory stimuli in complete brachial plexus injury is very important. The objective of our study was to evaluate sensory recovery in brachial plexus surgery using the intercostobrachial nerve (ICBN) as the donor. Methods: Eleven patients underwent sensory reconstruction using the ICBN as a donor to the lateral cord contribution to the median nerve, with a mean follow-up period of 41 months. A protocol evaluation was performed. Results: Four patients perceived the 1-green filament. The 2-blue, 3-purple and 4-red filaments were perceptible in one, two and three patients, respectively. According to Highet's scale, sensation recovered to S3 in two patients, to S2+ in two patients, to S2 in six patients, and S0 in one patient. Conclusion: The procedure using the ICBN as a sensory donor restores good intensity of sensation and shows good results in location of perception in patients with complete brachial plexus avulsion.
\end{abstract}

Keywords: brachial plexus; intercostal nerves; median nerve; nerve transfer; sensation; perception.

RESUMO

Objetivo: A restauração da sensibilidade em pacientes com lesão completa do plexo braquial é muito importante. 0 objetivo desse estudo foi avaliar a recuperação sensitiva em cirurgia do plexo braquial utilizando o nervo intercostobraquial (NICB) como doador. Métodos: Onze pacientes foram submetidos a reconstrução sensitiva usando o NICB como doador para a contribuição lateral do nervo mediano, com tempo de acompanhamento pós-operatório médio de 41 meses. Um protocolo de avaliação foi realizado. Resultados: Quatro pacientes perceberam o filamento 1-verde. Os filamentos 2-azul, 3-roxo e 4-vermelho foram percebidos por um, dois e três pacientes, respectivamente. Um paciente não apresentou recuperação sensitiva. Dois pacientes obtiveram recuperação S3, dois S2+, seis S2 e um S0, pela escala de Highet. Conclusão: O procedimento usando o NICB como doador promove boa intensidade de recuperação sensitiva e bons resultados são obtidos quanto ao local de percepção em pacientes com avulsão completa do plexo braquial.

Palavras-chave: plexo braquial; nervos intercostais; nervo mediano; transferência de nervo; sensação; percepção.

The treatment of complete brachial plexus avulsion remains a challenge for nerve surgeons ${ }^{1,2}$. The recovery of motor function continues to be the priority in brachial plexus reconstruction, but restoration of the sensitivity to sensory stimuli in the hand of patients who have regained movement and function in their arms should also be a priority.
In a previous study, our group demonstrated the anatomical feasibility of using the intercostobrachial nerve (ICBN) as a donor of sensory fibers to the lateral cord contribution to the median nerve (LCMN) ${ }^{3}$. The purpose of this study was to report the detailed clinical results of sensory recovery in the hand, using this technique in patients with complete brachial plexus injury.

\footnotetext{
'Universidade de São Paulo, Faculdade de Medicina, Hospital das Clínicas, Divisão de Neurocirurgia Funcional, Grupo de Cirurgia de Nervos Periféricos. São Paulo SP, Brasil;

${ }^{2} U$ niversidade de São Paulo, Faculdade de Medicina, Hospital das Clínicas, Departamento de Neurologia, São Paulo SP, Brasil;

${ }^{3}$ Instituto Fleury, Departamento de Neurofisiologia, São Paulo SP, Brasil;

${ }^{4}$ Universidade de São Paulo, Departamento de Neurologia, Divisão de Neurocirurgia, São Paulo SP, Brasil;

${ }^{5}$ Universidade de São Paulo, Faculdade de Medicina, Hospital das Clínicas, Terapia de Mão, São Paulo SP, Brasil.

Correspondence: Luciano Foroni; Rua Mateus Grou, 340 / apto. 22; 05415-040 São Paulo SP, Brasil; E-mail: lucianoforoni@yahoo.com.br

Conflict of interest: There is no conflict of interest to declare.

Received 30 July 2017; Accepted 14 August 2017.
} 


\section{METHODS}

\section{Patients}

All procedures performed in our study were in accordance with the ethical standards of the institutional and/or national research committee and with the 1964 Helsinki declaration and its later amendments or comparable ethical standards.

A prospective study was conducted from January 2010 to April 2013. Eighteen patients with complete brachial plexus injuries underwent motor and, at the same time, sensory reconstruction. In all cases, the mechanism of injury was high-energy trauma as the result of a motorcycle accident. Six patients were lost to follow-up and were not included in this analysis (patients 1, 4-7 and 15).

Twelve patients with a sufficient follow-up period received a complete evaluation of sensory recovery of the hand by an experienced hand therapist and were included in this study. One of the patients was excluded later because he was surgically treated with a DREZotomy (patient 8 ). The mean follow-up period was 41 months (range, 36-52 months). There were 10 male patients and one female patient. The mean age was 25 years old (range, 17-36 years old). The mean interval between injury and surgery for sensory reconstruction was 6.7 months (range, 2-11 months).

\section{Surgical technique}

Motor reconstructions were carried out on all patients and the sensory reconstruction was performed in the same surgery as follows: a longitudinal incision was made along the anterior axillary line starting in the posterior part of the lateral border of the pectoralis major muscle and prolonged downward until the third intercostal space. Fat tissue in the axillar region was dissected and carefully mobilized. The ICBN was identified within this fat tissue emerging from the second intercostal space and dissected distally towards the lateral chest skin and axillar region. The ICBN was then transected distally and reflected towards the infraclavicular space to reach the LCMN below the pectoralis major muscle. A deltopectoral incision was made, the cephalic vein was mobilized and the deltoid and the pectoralis major muscles were retracted apart. The pectoralis minor muscle was divided near its origin from the coracoid process to expose the infraclavicular plexus beneath the fat pad. The LCMN was isolated and divided at its origin in the lateral cord, to be turned down towards the axilla. Depending on the length of the LCMN and of the ICBN, the coaptation was made in the infraclavicular region, in the axilla or below the pectoralis major muscle. Two nylon 10-0 stitches and fibrin glue were applied for coaptation (Figures 1 and 2).

\section{Evaluation of sensory recovery}

A protocol evaluation was performed on 12 patients. The sensitivity in the distribution of the median nerve in the hand was evaluated when the advancement of the Tinel sign reached the carpal region.
Sensory tests were performed with the patient's eyes covered. The sites of sensory testing were the first three fingers and thenar eminence of the hand.

\section{Semmes-Weinstein monofilament test}

Pressure thresholds were evaluated using the Semmes-Weinstein monofilament test (Sorri-Bauru, Bauru, Brazil) $)^{4}$, with adequate technique. The filaments were differentiated by colors as 1-green ( $0.05 \mathrm{~g}), 2$-blue ( $0.2 \mathrm{~g}), 3$-purple ( $2.0 \mathrm{~g})$, 4-red (4.0 g), 5-orange (10.0 g) and 6-pink (300 g). The color black was used when no response was obtained. The lowest filament number detected reliably on two or more of four trials was recorded.

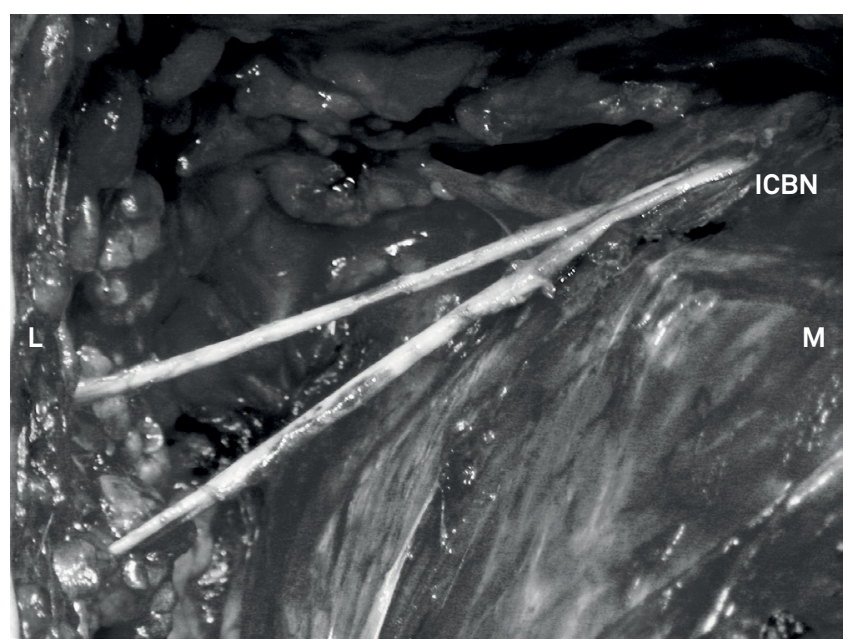

ICBN: intercostobrachial nerve; L: lateral; M: medial.

Figure 1. Surgical photography of a lateral view of the thorax showing the ICBN at its origin in the second intercostal space and crossing to the axilla.

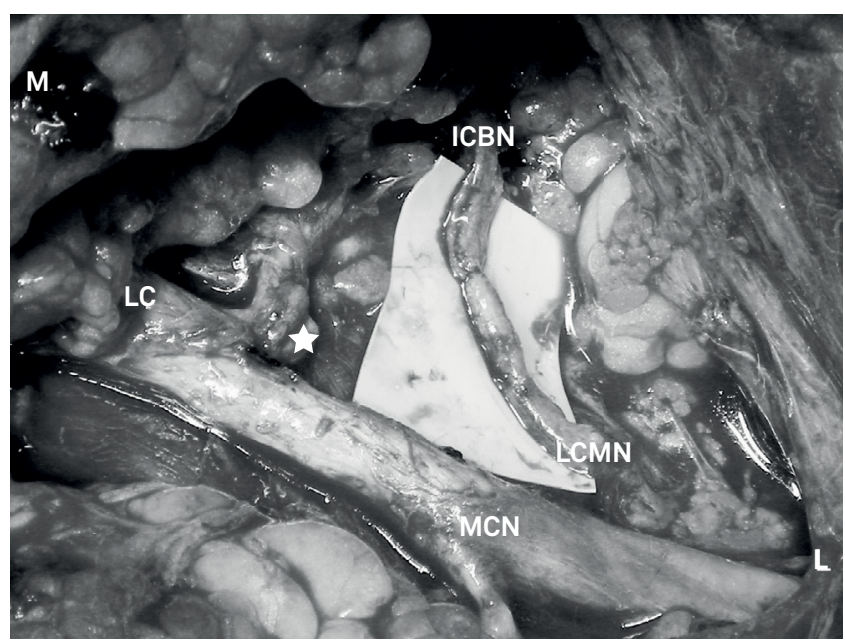

ICBN: intercostobrachial nerve; L: lateral; LC: lateral cord; LCMN: lateral cord contribution to the median nerve; M: medial; MCN: musculocutaneous nerve $\star$ : point where the LCMN was sectioned from the LC to be turned inferiorly for coaptation with the ICBN

Figure 2. After being sectioned distally and displaced in the subpectoral space, the ICBN reaches the LCMN in the deltopectoral groove. 


\section{Location of perception of sensation}

The location of perception of sensation in the median nerve territory of the hand was assessed using moving touch with the lowest monofilament detected.

\section{Vibration perception}

Perception of vibration was assessed with a tuning fork of 256-cycles/second stimuli touching directly on the sites of testing by the examiner. The results were recorded as being perceptible or not perceptible and where the location of perception was.

\section{Temperature perception}

A steel bar warmed in $50^{\circ} \mathrm{C}$ hot water and an ice bar were used for these tests, and were recorded as warmth being perceptible or not, and as cold being perceptible or not, respectively. The steel bar and ice bar were touched directly on the sites of testing by the examiner.

\section{Static and moving two-point discrimination}

The two-point discrimination tester developed by Mackinnon and Dellon was used for these tests ${ }^{5}$, using the methods described by Dellon ${ }^{6}$.

The results of sensory recovery were classified according to Highet's scale ${ }^{7.8}$.

S0: No recovery of sensitivity in the autonomous zone of the nerve;

S1: Recovery of deep cutaneous pain sensation within the autonomous zone of the nerve;

S1+: Recovery of superficial pain sensitivity;

S2: Recovery of superficial pain and some touch sensitivity;

$\mathrm{S} 2+$ : As in S2, but with overresponse;

S3: Recovery of pain and touch sensitivity with disappearance of the overresponse;

S3+: As in S3, but localization of the stimulus is good and there is imperfect recovery of two-point discrimination;

S4: Complete recovery;

\section{RESULTS}

Ten patients perceived at least the 4-red filament at the territory of the median nerve. The best result on Semmes-Weinstein monofilament testing was perception of the 1-green filament in four patients. The 2-blue filament was perceptible in one patient, the 3-purple in two patients and the 4-red in three patients.

Six patients felt sensation only in the cutaneous distribution of the repaired nerve in the hand. One patient had double sensation in the cutaneous distribution of both the median nerve in the hand and in the posteromedial aspect of the proximal arm that corresponded to the cutaneous distribution of the ICBN. Three patients had referred sensitivity only in the cutaneous distribution of the ICBN.

Vibration with 256-cycles/second stimuli was perceived in seven patients. Ten patients had perception of both warmth and cold. None of the patients had two-point discrimination. One patient experienced no sensory recovery at all.

According to the Highet scale, sensation recovered to S3 in two patients, to $\mathrm{S} 2+$ in two patients, to $\mathrm{S} 2$ in six patients, and $\mathrm{S} 0$ in one patient.

These data are shown in Table 1.

\section{DISCUSSION}

The anesthetic hand in complete brachial plexus avulsion exposes patients to secondary injuries'. With the objective of promoting protection to the patient's hands and fingers, sensory reconstruction should be one of the priorities of the surgery. However, often treatment is focused only on motor recovery and the sensory recovery is neglected.

The median nerve should be the recipient nerve for sensory reconstruction because of its wider sensory cutaneous distribution in the hand, including the pinch territory. Previous studies have described limited results using grafts, supraclavicular nerve, intercostal nerves or contralateral C7 as donors ${ }^{10-24}$. Detailed data are shown in Table 2.

Table 1. Sensory recovery results.

\begin{tabular}{|c|c|c|c|c|c|c|}
\hline Case number & Highet's scale & $\begin{array}{c}\text { Monofilament } \\
\text { detected }\end{array}$ & $\begin{array}{l}\text { Location of } \\
\text { perception }\end{array}$ & $\begin{array}{l}\text { Vibration } \\
\text { perception }\end{array}$ & $\begin{array}{c}\text { Temperature } \\
\text { perception }\end{array}$ & $\begin{array}{c}\text { Two-point } \\
\text { discrimination }\end{array}$ \\
\hline 2 & S2 & 3-purple & arm & $(+)$ & $(+)$ & $(-)$ \\
\hline 3 & S2 & 2-blue & arm & $(+)$ & $(+)$ & $(-)$ \\
\hline 9 & S2 & 4-red & hand & $(-)$ & $(+)$ & $(-)$ \\
\hline 10 & S2 & 4-red & hand & $(-)$ & $(+)$ & $(-)$ \\
\hline 11 & S2 & 3-purple & arm & $(+)$ & $(+)$ & $(-)$ \\
\hline 12 & $\mathrm{~S} 2+$ & 1-green & hand & $(+)$ & $(+)$ & $(-)$ \\
\hline 13 & S2 & 4-red & hand & $(-)$ & $(+)$ & $(-)$ \\
\hline 14 & S3 & 1-green & hand & $(+)$ & $(+)$ & $(-)$ \\
\hline 16 & $\mathrm{~S} 2+$ & 1-green & hand & $(+)$ & $(+)$ & $(-)$ \\
\hline 17 & so & black & $(-)$ & $(-)$ & $(-)$ & $(-)$ \\
\hline 18 & S3 & 1-green & Hand and arm & $(+)$ & $(+)$ & $(-)$ \\
\hline
\end{tabular}


Table 2. Results of sensory recovery in previous studies.

\begin{tabular}{|c|c|c|}
\hline Author(s), year & Number of patients / donor(s) & Results \\
\hline Kotani et al., $1971^{11}$ & $15 / \mathrm{ICNs}$ & Limited sensitivity in 11 patients \\
\hline Millesi, $1977^{12}$ & 18 / grafts or ICNs & Protective sensitivity in 15 patients \\
\hline Narakas and Hentz, $1988^{13}$ & $9 / \mathrm{ICNs}$ & "Good recovery" in 4 patients \\
\hline Sedel, $1982^{14}$ & 22 / grafts or ICNs & S1 in 14 patients \\
\hline Kawai et al., $1988^{15}$ & $13 / \mathrm{ICNs}$ & S2 in 5 patients \\
\hline Nagano et al., $1989^{16}$ & $4 / \mathrm{ICNs}$ & Protective sensitivity in 4 patients \\
\hline Ogino e Naito, $1995^{17}$ & $10 / \mathrm{ICNs}$ & Protective sensitivity in 10 patients \\
\hline Ihara et al., $1996^{18}$ & $13 / \mathrm{ICN} \sin 3$ and SCN in 10 & S2 in 3 patients using ICNs and S2 in 2 patients using SCN \\
\hline Gu et al., $1998^{19}$ & $8 / \mathrm{CC} 7$ & S3 in 6 patients \\
\hline Songchaoren et al., $2001^{20}$ & $21 /$ CC7 & S3 in 10 patients, $S 2$ in 7 patients \\
\hline Chen et al., $2007^{21}$ & 12 children / CC7 & S3+ in 6 patients, S3 in 6 patients \\
\hline Terzis et al., $2008^{22}$ & $29 /$ CC7 & S3 in 12 patients, $S 2$ in 10 patients \\
\hline Hattori et al., $2009^{10}$ & $17 /$ ICNs and/or ICBN & $\mathrm{S} 2+$ in 2 patients, $\mathrm{S} 2$ in 9 patients, $\mathrm{S} 1$ in 6 patients \\
\hline Gao et al., $2013^{23}$ & 22 / CC7 & S3 in 10 patients \\
\hline El-Gammal et al., $2014^{24}$ & 5 children / ICNs or CC7 & S2 in 5 patients \\
\hline
\end{tabular}

CC7: contralateral C7; ICBN: intercostobrachial nerve; ICNs: intercostal nerves; SCN: supraclavicular nerve.

The study by Hattori et al. ${ }^{10}$ is the only one in the literature mentioning the use of the ICBN as a donor in sensory nerve transfers for the hand. They speculated that they had better results than previous studies as a consequence of the use of the ICBN, in association with other intercostal nerves.

To evaluate the use of the ICBN exclusively, as a donor of sensory fibers to the LCMN, we conducted this clinical study.

The location of perception in the previous studies was in the donor nerve(s) territory, with the exception of two patients in the study by Hattori et al. ${ }^{10}$, who felt the stimuli in the recipient nerve territory. That means that if the donor was the supraclavicular nerve, a stimulus made in the hand was felt in the supraclavicular region; in the lateral chest with the intercostal nerves as donors, and in the contralateral arm with $\mathrm{C} 7$ as donor. This could be explained by the fact that these areas are in different and distant regions of the brain map, as proposed by Penfield and Boldrey ${ }^{25}$.

The need for better results for sensory recovery in the hand following brachial plexus surgery, in terms of the intensity of sensation (Highet's scale) and location of perception, led us first to conduct an anatomical study that demonstrated the feasibility of the ICBN to the LCMN sensory nerve transfer ${ }^{3}$, with some very interesting results using this technique.

After a nerve lesion, a topographical reorganization of the somatosensory cortex occurs, resulting in a rapid invasion of the previous nerve cortical area by the adjacent nerves $\operatorname{areas}^{26,27}$. Then, as the ICBN is a branch of the second intercostal nerve ${ }^{28}$ that innervates a cutaneous area covering the axilla and posteromedial aspect of the $\operatorname{arm}^{29}$, it is possible that its cortical area expands after a complete brachial plexus avulsion invading the whole arm cortical territory.

We believe that the ICBN has a great advantage over other nerve donors because of these inherent conditions and proximity of its cortical area to the median nerve area, facilitating the cerebral plasticity. This could explain why our results, in terms of location of perception, are better than those of previous studies, and are better or similar to the best results of prior studies in adults, in terms of intensity of perception.

In conclusion, the ICBN as a sensory donor has the advantage of restoring a good intensity of sensation, and the best result in location of perception, when compared to other nerve donors. This technique may be helpful for nerve surgeons dealing with the devastating complete brachial plexus avulsion.

\section{References}

1. Narakas AO. Thoughts on neurotization of nerve transfers in irreparable nerve lesions. In: Terzis JK, editor. Microreconstruction of nerve injuries. Philadelphia: WB Saunders; 1987. p. 447-54.

2. Belzberg AJ, Dorsi MJ, Storm PB, Moriarity JL. Surgical repair of brachial plexus injury: a multinational survey of experienced peripheral nerve surgeons. J Neurosurg. 2004;101(3):365-76. https://doi.org/10.3171/jns.2004.101.3.0365

3. Foroni L, Siqueira MG, Martins RS, Oliveira GP. The intercostobrachial nerve as a sensory donor for hand reinnervation in brachial plexus reconstruction is a feasible technique and may be useful for restoring sensation. Arq Neuropsiquiatr. 2017;75(7):439-45. https://doi.org/10.1590/0004-282×20170073
4. Lehman LF, Orsini MBP, Nicholl ARJ. The development and adaptation of Semmes-Weinstein monofilaments in Brazil. J Hand Therapy.1993;6(4):290-7.https://doi.org/10.1016/S0894-1130(12)80330-9

5. Mackinnon SE, Dellon AL. Two-point discrimination tester.J Hand Surg.1985;10(6 Pt 1):906-7.https://doi.org/10.1016/S0363-5023(85)80173-8

6. Dellon AL. The moving two-point discrimination test: clinical evaluation of the quickly adapting fiber/receptor system.J Hand Surg. 1978;3(5):474-81. https://doi.org/10.1016/S0363-5023(78)80143-9

7. Dellon AL, Curtis RM, Edgerton MT. Reeducation of sensation in the hand after nerve injury and repair. Plast Reconstr Surg. 1974;53(3):297-305. https://doi.org/10.1097/00006534-197403000-00008 
8. Mackinnon SE, Dellon AL. Surgery of the peripheral nerve. New York: Thieme; 1988.

9. Ruchelsman DE, Price AE, Valencia H, Ramos LE, Grossman JA. Sensory restoration by lateral antebrachial cutaneous to ulnar nerve transfer in children with global brachial plexus injuries. Hand (N Y). 2010;5(4):370-3. https://doi.org/10.1007/s11552-010-9284-6

10. Hattori Y, Doi K, Sakamoto S, Yukata K. Sensory recovery of the hand with intercostal nerve transfer following complete avulsion of the brachial plexus. Plast Reconstr Surg. 2009;123(1):276-83. https://doi.org/10.1097/PRS.0b013e31819348a7

11. Kotani T, Toshima Y, Matsuda H, Suzuki T, Ishizaki Y. Postoperative results of nerve transposition in brachial plexus injury. Seikeigeka. 1971;22(11):963-6.

12. Millesi H. Surgical management of brachial plexus injuries. J Hand Surg. 1977;2(5):367-78. https://doi.org/10.1016/S0363-5023(77)80046-4

13. Narakas AO, Hentz VR. Neurotization of brachial plexus injuries: indication and results. Clin Orthop. 1988;(237):43-56.

14. Sedel L. Repair of severe traction lesion of the brachial plexus. ClinOrthop.1988;(237):62-3.

15. Kawai H, Kawabata H, Masada K, Ono K, Yamamoto K, Tsuyuguchi Y, Tada K. Nerve repairs for traumatic brachial plexus palsy with root avulsion. Clin Orthop Relat Res.1988;(237):75-86.

16. Nagano A, Tsuyama N, Ochiai N, Hara T, Takahashi T. Direct nerve crossing with the intercostal nerve to treat avulsion injuries to the brachial plexus. J Hand Surg Am.1989;14(6):980-5. https://doi.org/10.1016/S0363-5023(89)80047-4

17. Ogino T, Naito T. Intercostal nerve crossing to restore elbow flexion and sensibility of the hand for a root avulsion type of brachial plexus injury. Microsurgery.1995;16(8):571-7. https://doi.org/10.1002/micr.1920160812

18. Ihara K, Doi K, Sakai K, Kuwata N, Kawai S. Restoration of sensibility in the hand after complete brachial plexus injury.J Hand Surg. 1996;21(3):381-6. https://doi.org/10.1016/S0363-5023(96)80348-0

19. Gu YD, Chen DS, Zhang GM, Cheng XM, Xu JG, Zhang LY et al. Long-Term functional results of contralateral C7 transfer.J Reconstr Microsurg.1998;14(1):57-9.
20. Songcharoen P, Wongtrakul S, Mahaisavariya B, Spinner RJ. Hemi-contralateral C7 transfer to median nerve in the treatment of root avulsion brachial plexus injury.J Hand Surg Am.2001;26(6):1058-64. https://doi.org/10.1053/jhsu.2001.27764

21. Chen L, Gu YD, Hu SN, Xu JG, Xu L, Fu Y. Contralateral C7 transfer for the treatment of brachial plexus root avulsions in children: a report of 12 cases. J Hand Surg Am.2007;32(1):96-103. https://doi.org/10.1016/j.jhsa.2006.05.013

22. Terzis JK, Kokkalis ZT, Kostopoulos E. Contralateral C7 transfer in adult plexopathies. Hand Clin.2008;24(4):389-400. https://doi.org/10.1016/j.hcl.2008.04.003

23. Gao K, Lao J, Zhao X, Gu Y. Outcome of contralateral C7 transfer to two recipient nerves in 22 patients with the total brachial plexus avulsion injury. Microsurgery.2013;33(8):605-11. https://doi.org/10.1002/micr.22137

24. El-Gammal TA, El-Sayed A, Kotb MM, Saleh WR, Ragheb YF, El-Refai O. Delayed selective neurotization for restoration of elbow and hand functions in late presenting obstetrical brachial plexus palsy. J Reconstr Microsurg.2014;30(4):271-4. https://doi.org/10.1055/s-0033-1357280

25. Penfield W, Boldrey E. Somatic motor and sensory representation in the cerebral cortex of man as studied by electrical stimulation. Brain.1937;60(4):389-443. https://doi.org/10.1093/brain/60.4.389

26. Merzenich MM, Jenkins WM. Reorganization of cortical representations of the hand following alterations of skin inputs induced by nerve injury, skin island transfers and experience.J Hand Ther. 1993;6(2):89-104. https://doi.org/10.1016/S0894-1130(12)80290-0

27. Wall JT, Kaas JH, Sur M, Nelson RJ, Felleman DJ, Merzenich MM. Functional reorganization in somatosensory cortical areas $3 \mathrm{~b}$ and 1 of adult monkeys after median nerve repair: possible relationships to sensory recovery in humans. J Neurosci. 1986;6(1):218-33.

28. Williams PL, Bannister LH, Berry MM. Thoracic ventral rami. In: Williams PL, Bannister LH, Berry MM, editors. Gray's anatomy. 38th ed. London: Churchill Livingstone; 1999. p. 1275-6.

29. Morrow M. Segmental mastectomy and axillary dissection. In: Baker RJ, Fischer JE, editors. Mastery of surgery. 4th ed. Philadelphia: Lippincott Williams and Wilkins; 2001. p. 588-96. 